\title{
Recent developments in the application of risk analysis to waste technologies
}

\author{
S.J.T. Pollard ${ }^{\mathrm{a}, *}$, R. Smith ${ }^{\mathrm{a}}$, P.J. Longhurst ${ }^{\mathrm{a}}$, G.H. Eduljee ${ }^{\mathrm{b}}$ and D. Hall ${ }^{\mathrm{c}}$ \\ ${ }^{a}$ Integrated Waste Management Centre, School of Industrial \& Manufacturing Science, \\ Cranfield University, Cranfield Bedfordshire, MK43 OAL, United Kingdom \\ ${ }^{b}$ SITA Limited, Maidenhead, SL6 1ES, United Kingdom \\ ${ }^{c}$ Golder Associates (UK) Ltd., Nottingham, NG12 4DG, United Kingdom
}

\section{Abstract}

The European waste sector is undergoing a period of unprecedented change driven by business consolidation, new legislation and heightened public and government scrutiny. One feature is the transition of the sector towards a process industry with increased pre-treatment of wastes prior to the disposal of residues and the co-location of technologies at single sites, often also for resource recovery and residuals management. Waste technologies such as in-vessel composting, the thermal treatment of clinical waste, the stabilisation of hazardous wastes, biomass gasification, sludge combustion and the use of wastes as fuel, present operators and regulators with new challenges as to their safe and environmentally responsible operation. A second feature of recent change is an increased regulatory emphasis on public and ecosystem health and the need for assessments of risk to and from waste installations. Public confidence in waste management, secured in part through enforcement of the planning and permitting regimes and sound operational performance, is central to establishing the infrastructure of new waste technologies. Well-informed risk management plays a critical role. We discuss recent developments in risk analysis within the sector and the future needs of risk analysis that are required to respond to the new waste and resource management agenda.

Keywords: risk, analysis, waste, management, developments, process, technology

\section{Introduction}

Environmental risk assessment is an established feature of modern environmental decisions and has been used successfully to target risk management actions on the key drivers of risk across a range of anthropogenic and natural hazards (European Environment Agency, 1998). The basis of risk assessment (Vose, 2000) is an evaluation of the connectivity between the source of a hazard and an environmental receptor - something one wishes to protect. Without a "dose" - an amount or duration of exposure to a harmful agent, there can be no harm at the receptor and one purpose

\footnotetext{
${ }^{*}$ Corresponding author: Tel: +44-1234-754101; fax: +44-751671

E-mail address: s.pollard@cranfield.ac.uk (S.J.T.Pollard)
} 
of risk assessment must, therefore, be to evaluate the likelihood and consequences of determining this harm. Many regulators now promote a tiered approach to risk assessment that allows for an initial screening and prioritisation of risk prior to undertaking more detailed assessments (DETR et al., 2000). This assists in ensuring that problems are welldefined, that potential sources, pathways and receptors are comprehensively considered and that subsequent risk assessment effort and resources are focussed on the key risks identified at a screening stage.

The waste management sector applies risk assessment widely to issues such as the risks to groundwater from landfills (Environment Agency, 1996; Hall et al., 2003), the potential risks to human health from continuous stack emissions (Harrop and Pollard, 1998; Eduljee, 2001) and to the potential health impacts from exposures to landfill gas (Attenborough et al., 2002). The development of conceptual models, site-specific exposure scenarios and application of the source-pathway-receptor approach (DETR et al., 2000; Environment Agency, 2000; WHO, 2000), supported by quantitative analysis (Vose, 2000) where appropriate, is now commonplace. Environmental risk tools are based upon models that characterise pollutant pathways in open environmental systems and assume, or model, the release of the source of a hazard to the environment, be it through mechanisms such as liner failure, the episodic flux of emissions to air, or diffusive flow through a landfill cap. Modern groundwater risk assessments for landfills couple a performance assessment of the liner system (Environment Agency, 2001; Hall et al., 2003) with a contaminant transport model to assess potential risks to receptors such as downgradient abstraction boreholes (Figure 1). The numerical approach to characterising pathways of environmental exposure (e.g. groundwater dispersion or air diffusion) and modelling the distribution of contaminants in the environment, has proved powerful for the developers and operators of waste facilities in securing environmental permits (Garrick, 2002).

Fig. 1. Basis for the combined performance and risk assessment of landfills and their potential impact on downgradient abstraction points, here by reference to listed substances in the EC Groundwater Directive (Environment Agency, 2000).

A shift within the sector towards waste process technologies, and the attending concerns raised about the potential environmental harm (Dolk, 2002; Defra, 2004) that may result from routine, unmanaged or accidental releases to the environment however, is forcing a widening of the portfolio of risk tools required (National Research Council, 2000; Environment Agency, 2000). Furthermore, we are witnessing a more joined up approach to the assessment of risks from waste facilities (Environment Agency, 2004a), with a growing need to assess a larger set of causal events and subsequent exposures that might result in detrimental impacts - including issues of odour nuisance, exposure to trace 
components in landfill gas and to airborne microorganisms from biological waste treatment, losses in slope stability at landfills and risks from process failures in engineered systems. This paper discusses these developments and attempts a synthesis of the role of risk assessment in the modern waste and resource management sector.

\subsection{Risk analysis tools}

Risk assessment tools can be categorised by reference to the nature of the risk problem they are used to assess.

Generally, risk analysts are concerned with three categories of risk problem that can be considered as part of a causal chain of events (Pollard and Guy, 2001; Figure 2):

(i) source term risks associated with the risk of an initiating event or combination of events that deviate from normal operating conditions and may result in a release to the environment (e.g. fire risk; the loss of flame at a pumped landfill gas flare unit; the catastrophic release of fire wash down from an on-site collection tank; the risk of mixing incompatible wastes; a catastrophic landfill liner failure; inventory loss of treatment reagents or stored wastes; inappropriate mixing of hazardous wastes during treatment; CIRIA, 1997);

(ii) pathway risks that address the likelihood of a certain exposure of an environmental receptor to a hazard following an initial release (e.g. grounding of a plume downwind of an incinerator stack; movement of a leachate plume towards and abstraction point; off-site bioaerosol exposure from the turning of windrows at a composting facility; Pollard, 1999); and

(iii) the risks of harm to receptors that might occur as a result of the exposure (e.g. adverse human or ecological health effects as a result of exposure to toxic / asphyxiant gases; a toxic overload to biological wastewater treatment plant as a result of a shock load of hazardous waste illegally disposed of to foul sewer; occupational health effects experienced by workers at enclosed composting facilities; needlestick injuries and their consequences to medical waste management operatives).

Each of these types of problem has associated with it certain categories of risk analysis tools (Figure 2) that tend to dominate for the analysis in each case. In part, because of the regulatory separation between health and safety and environmental concerns, these tools have historically developed in isolation of one another with little connection between the outputs of one analysis and the input requirements of another. In the future, the integrated pollution and prevention control will ensure that these aspects are more integrated.

Fig.2. Basic typology of risk assessment tools and emphasis. 
Risk analysis tools are also available at a range of tiers of technical sophistication (qualitative, semiquantitative, quantitative-deterministic, quantitative-probabilistic; DETR et al., 2000; Pollard et al., 2002) and, in deciding on the application of techniques, risk analysts need to consider both (i) the appropriate tool by reference to the type of risk problem being studied (Figure 2); and (ii) an appropriate level of sophistication selected as needs, complexities, priorities and data allow (Pollard et al., 1995). Changes occurring within the sector are likely to remove the historic barriers between these types of risk problem and their analysis. New guidance for landfill operators in the UK, for example (Environment Agency, 2004a), promotes assessing and presenting the risks for a site as a whole, rather than considering the significance of risks from individual hazards in isolation of one another. This will allow operators and regulators to focus on the priority risks to health and the environment and identify common research needs for the improved understanding of landfill process, for example. Integrated pollution prevention and control is also forcing consideration of risk management at source (pollution prevention) as well as a comparative analysis of risks to the multimedia environment. Under these developments, a broader set of risks (other than just to the aquatic and atmospheric environment) require analysis and comparison.

\section{Developing a portfolio of risk analysis tools}

\subsection{Process risk analysis}

In the modern waste sector, much of the waste processing required prior to residuals management will occur in engineered systems, with linked unit processes. Whilst not at the scale or sophistication of the chemicals process sector, waste technologies adopt process engineering principles in their design and optimisation. Here, material flows and mass balances are represented by process flowsheets (Figure 3) and system layout diagrams. The performance of, and risks from, unit processes can be assessed using tools such as failure mode and effects analysis (FMEA) and event tree analysis (ETA). These tools, used widely in the chemical, oil, nuclear and water sectors, are increasingly applied to waste process flowsheets. They offer the advantage of representing the process system in its entirety and allow vulnerabilities to process failure to be assessed. Though not infallible and requiring application with strict reference to operational expertise (HSE, 2003), these tools can be used to infer the key routes of environmental exposure following a release, providing the system is properly represented, and so inform the prioritisation of risk management actions, including contingency planning in the future. One might reasonably imagine that some of the more common waste management facility incidents experienced in the UK (the inappropriate mixing of wastes during treatment, loss of 
stored wastes to the aquatic environment) might have been avoided through the active adoption of process risk analysis during design, plant layout and operation.

Fig. 3. Simplified process flowsheet for the two-step anaerobic degradation plant, Sobacken, Borås, Sweden for wet organic household waste (after Ecke et al., 1997). The unit process sequence includes a mixing tank, a hydrolysis reactor, dewatering, a methanogenic filter and a nitrification tower. The plant started operation in 1995 with an annual capacity of $c a$. $9000 \mathrm{t}$ of organic waste fraction. The digestate is post-treated by composting.

Fault tree analyses select an undesired event (such as an engineering failure, a fire or an inadvertent mixing of incompatible wastes) and trace it back to the possible system causes, which can be component failures, human error or other factors that could lead to the undesired 'top' event. The causes are related using Boolean logic relationships (i.e. AND/OR 'gates') to allow the root causes of the failure of the system to be identified and modelled (Figure 4). Where quality reliability data are available, quantitative FMEA allows conditional probabilities to be assigned to the various failure modes.

Fig. 4 Illustrative and qualitative fault-tree for release of compost liquor to groundwater at a composting plant showing AND and OR gates.

The nuclear sector has made long-standing and extensive use of FMEA in its performance assessments of radioactive waste repositories (Watts, 2001; BNFL, 2002) and some of these engineering risk tools are now being applied to conventional hazardous waste management facilities in the US and Europe (Garrick, 2002; Shaw et al., 2002).

In contrast, event tree analysis starts with the initiating event (e.g. the failure of a leachate treatment system, the release of a cloud of hazardous gas; the overflow of an oil/water interceptor) and sets out the onward consequences of the release - the environmental consequences of a process accident, for example. As with many risk techniques, fault and event tree analyses require process data to quantify the contributory causes and consequences and their contingent probabilities, though both may be used qualitatively. Data can be difficult to source and quantification relies on expert judgments made on the basis of performance data and long-standing operational expertise. Event tree analysis is seeing particular use for quantitative microbial risk assessment (Figure 4); for example, in the assessment of pathogenic risks from the disposal of sewage sludge to land on which crops may be grown for human consumption (Gale, 2001), in assessing the pathogenic risks of composting of meat-containing catering wastes, and in assessing the potential risks to human health from the disposal and onward environmental fate of transmissible spongiform encephalopathy (TSE) 
agents (Hirschhorn, 1999; BRS, 2001; WRc, 1998; Figure 5). Whilst offering presentational clarity, however, the application of tools used conventionally for closed engineered systems to open environmental settings has its limitations, in that a certain uniformity of structure is imposed on the fate and transport of agents within the environment. The construction of event trees for environmental exposures is open to conceptual bias in this sense and one must be especially cautious of quantitative tools in this regard, because mass balances treated as single 'legs' in an event tree may in reality be dispersed among several environmental compartments.

Fig. 5 Illustrative event tree for of the fate of infective doses (ID) of pathogenic agents during the proposed rendering of over thirty month scheme (OTMS) material in a fictitious rendering plant (adapted from WRc, 1998, used with permission)

The requirements of the European Council (EC) Landfill Directive (1999/31/EC) on the progressive reduction of biodegradable waste, the growth in waste processing and the additional requirement under integrated pollution, prevention and control to assess the risks of accidents and their consequences for waste management installations are likely to encourage greater use of risk tools for assessing process failures (e.g. of leachate treatment plant, of gas collection and combustion systems, of emissions control equipment) and the significance of risks from combined hazards, such as from flooding at hazardous waste storage treatment facilities. In this regard, hazard and operability (HAZOP) tools for assessing process safety, and hazard analysis critical control point (HACCP) frameworks for identifying risk-critical points in multi-unit systems can also be applied to waste processing. The latter approach, adapted from the food technology literature and reviewed for the water sector in this volume, features in European proposals for the management of pathogenic hazards from biosolids (Godfree, 2001) and composting practices under proposed European legislation.

\subsection{Environmental exposures and risk}

Environmental systems are open, complex, dynamic and heterogeneous. Risks to and from the environment are determined within a combined spatial and temporal context. Models of the environment for its analysis (Schnoor, 1996) often belie this reality but, in simplifying the system, offer the benefit of rational analysis within the confines of the model constructed. Using conceptual models it is possible to assess exposures within the system boundaries and postulate the relative probabilities of exposure mediated through environmental systems. In doing so, risk analysts aim to identify and prioritise key routes of exposure and, where exposures are found to be unacceptable, propose 
management responses accordingly. Given the complexity involved, practitioners often resort to numerical approaches that allow subtle distinctions between the drivers of exposure to be explored by sensitivity analyses. Conventionally, but by no means universally, quantitative risk assessment is reserved for exposures that are already deemed significant.

With respect to the exposure dose, the magnitude, frequency, timing and duration of exposure are important concepts in determining the extent of potential harm from waste processing operations. The presence and maintenance of barriers (physical, engineered, biological, environmental, behavioural) to exposure can often be important in minimising public health risks and when removed or bypassed by accident or design, can dramatically increase the likelihood of exposure by orders of magnitude. Examples might include the ingress of gas into buildings through poor service pipe installations, poor liner welds in engineered landfill liners, an absence of security to land contaminated with hazardous waste. Direct pathways involve exposure to the medium in which the source resides- the direct inhalation of hazardous vapours, for example. Indirect pathways usually involve transport of the source between media, such as the leaching of contaminants from a landfill site through permeable strata to a groundwater aquifer, or the carry over of persistent compounds through the various unit processes of a poorly performing leachate treatment works. Whilst concern is usually reserved for direct exposures through inhalation and ingestion routes, risks may be driven by direct or indirect exposure to the source of the hazard.

Dispersion modelling is one approach to quantifying the spatial extent of exposures to the wider environment from a point or area source. Human health and amenity risk assessments that assess the impacts of odour and particles downwind of landfills and other operating installations adopt such approaches (Hester and Harrison, 2002; Taha and Pollard, 2004). Many treatment processes such as windrow composting and the bioremediation of organic wastes emit odours, bioaerosols and/or volatiles (Steinheider et al., 1998). The off-site impacts of these hazards are conventionally assessed by reference to exposure point concentrations or doses experienced by a receptor at distance from the source. Figure 6 illustrates this type of assessment used in support of an environmental statement, where odour unit concentrations are specified as a percentile of total hours in the year to interpret levels of annoyance that could be experienced by a local population. Risk assessments for bioaerosols, dust, and odour frequently have to account for the significance of such impacts by defining permissible emission limits at source, through back-calculation, or reverse modelling of an exposure point concentration. As with noise limit models, these approaches attempt to define maximum permissible levels by accounting for the existing baseline of impacts from other nearby sources as well as the incremental impacts from the facility in question. Disaggregating these individual contributions is methodically complex and frequently not possible. 
Fig. 6. The application of distribution models in exposure assessment for amenity risk assessment. Map shows contours of increasing odour units (ou; from outer contours, inward) of $1,3,5 \mathrm{ou} / \mathrm{m}^{3}$, presented here as boundaries beyond which values are not exceeded for more than $2 \%$ of the time (Shanks Waste Services, 2003; location plan reproduced from the revised 1998 Ordnance Survey 1:50 000 Landranger map No. 153 with the permission of the Controller of Her Majesty's Stationery Office, (c) Crown copyright.)

Controlling detrimental impacts from pollutants is further complicated where exposure limits are not defined but where annoyance impacts may still be significant. The need to assess the significance of low concentrations of pollutants in the ambient environment is especially evident where impacts on local amenity arise, because communities may assume that presence of an odour confirms exposure to hazardous compounds. Risk-based approaches, evident within the forthcoming European Directive on Noise, provide a consistent policy for operators to define process design standards. Harmonised approaches using risk tools to inform odour management plans are being established across international companies (Senate et al., 2004) and promoted during policy development (Van Broeck, 2004).

Modelling the environmental distribution of contaminants from waste management facilities has highlighted the susceptibility of environmental risk assessments to the availability and quality of data on source terms (Environment Agency, 2004b). Notwithstanding the widely acknowledged difficulties encountered in measuring releases from these types of facility, bioaerosol, gas and vapour emissions at waste installations are frequently episodic (rather than continuous) and often related to operational process cycles, diurnal and daily fluctuations in air temperature and pressure or phase changes in contaminant behaviour (Rabl and Spadaro, 2002). Under these circumstances, conventional dispersion models may prove inappropriate for estimating off-site exposures (Hobbs et al., 2003; Taha and Pollard, 2004) especially over short distances and may require amendment.

Within regulatory risk assessment, there is a need to scrutinise the total mass balance of waste systems and account for total losses to the full set of environmental compartments, so that while one aspect of the impact is fully assessed (and regulated), other pathways are not inadvertently ignored (e.g. Mills et al., 2004). For example, the impact on groundwater of new landfills rarely assesses the other routes that contaminants might take, such as bulk flows to a treatment plant, volatile emissions to the atmosphere, or discharges to surface water. The single environmental compartment approach historically adopted by many risk assessments has been in response to regulation of the specific receiving body (groundwater, surface water, air), but in future, risk assessments for waste installations under integrated pollution prevention and control will adopt a more integrated approach, that views potential impacts by reference to 
multimedia (air, water, land, biota) routes of exposure (Environment Agency, 2004a) to a range of receptors within the environmental setting. Further, with the emphasis now firmly on pollution prevention, risk assessments can be expected to better inform preventative pollution strategies and risk management plans rather than focusing on the impacts of releases post-event.

Understanding the temporal aspects of exposure is equally important - for example, characterising the long term risks to the environment during the management of treatment residuals and understanding the episodic nature of exposures, highlighted above. The sustainable development agenda has forced a consideration of intergenerational timeframes within the performance assessment of the engineered landfill environment, with 30 years being frequently considered as a regulatory benchmark for risks into the future. Whilst knowledge of leachates from conventional (largely municipal solid waste co-disposal) landfill sites in the UK is considerable, the UK has far less experience at hand to inform the management of risks associated with leachate from post-Landfill Directive sites (Environment Agency, 2004b). Unlike several EU Member States, where national legislation has required alternatives to landfill for a number of years, the UK has not relied heavily on incineration and mechanical and biological pre-treatment. The expectation is that post-Landfill Directive sites will be characterised by significantly reduced degradable carbon loadings and dominated by chemical rather than biological processes, but there is considerable uncertainty surrounding the characterisation of environmental fate processes, emissions and long-term risks. Adaptation of risk analysis approaches used elsewhere in radioactive waste performance assessment however, is demonstrating that much longer management timescales than those considered to date are likely to be relevant (Figure 7). When the long term fate of contaminants in landfill is modelled beyond the current regulatory requirement of 30 years, extended periods of operational and institutional control may be required (Hall et al., 2004).

Fig.7. Estimated management period of $340 \mathrm{y}$ for a non-flushing landfill accepting raw municipal solid wastes (MSW)

and meeting the water quality standard (WQS) for lead at a groundwater receptor (after Hall et al., 2004)

Hall et al. (2004) suggest that for true landfill equilibrium status, where each and every contaminant in the landfill environment meets a required assessment endpoint, that maximum management periods in excess of 2000 years for persistent contaminants in certain residues may be required. These timescales raise important regulatory and operational issues over operational, post-operational, post-closure and post-institutional control periods and the timing and nature of regulatory interventions for managing risk. Drawing on decades of international experience in the 
development of safety cases for radioactive waste repositories (Nuclear Energy Authority, 1999), Yearsley and Summerling (2002) conclude:

- The possibility of impacts arising in the far future is an inevitable consequence of the decision to concentrate and contain waste. The observation that any repository can be sited and designed such that significant impacts are estimated to only occur at very long times in the future is a positive feature and measure of success of the waste management solution.

- No single time scale is likely to be acceptable to all audiences of a risk assessment or for all the motivations that underlie the use of long timescales. Safety cases need to use different arguments, lines of evidence and calculations at different timescales to provide confidence.

- Common sense should be exercised in the presentation of risks over extended time periods and if results to long timescales are presented then the associated uncertainties and their interpretation should be explained.

- Dialogue with the wider scientific community and the public could inform the safety case and the time scales adopted. Whilst the public is recognised a heterogeneous group that will bring a wide range of personal values to any dialogue process, such dialogue might lead to different emphases on the time scales adopted in safety assessments, possibly with less emphasis on extremely long time scales (100 000 years for radioactive waste).

These observations offer important lessons for the non-radioactive waste community as they formulate the approach to assessing exposures in the long term and the consequences and timing of environmental harm. The adoption of integrated waste management that delivers the waste hierarchy would likely address the health risks associated with individual waste management options (South West Public Health Observatory, 2002), through process control. But this also requires the segregation and treatment of waste at co-located facilities, and risk management upstream in the process cycle. Many of the risks that arise in the latter stage of the process cycle, i.e. during waste management, are a consequence of actions taken at earlier stages of design, production, packaging and marketing. Ultimately, chemical hazards from waste residues must be managed at source through the elimination of hazardous components from the design process.

\subsection{Environmental harm}

For environmental receptors, the risk of potential environmental harm following a release (accidental or consented) and a subsequent exposure (Figure 2) is characterised by the dose-response curve (Figure 8) - the relationship 
between the exposure to or intake of a hazardous agent and its toxicological (or chemical, or physical) effect on the receptor (Dolk, 2002)

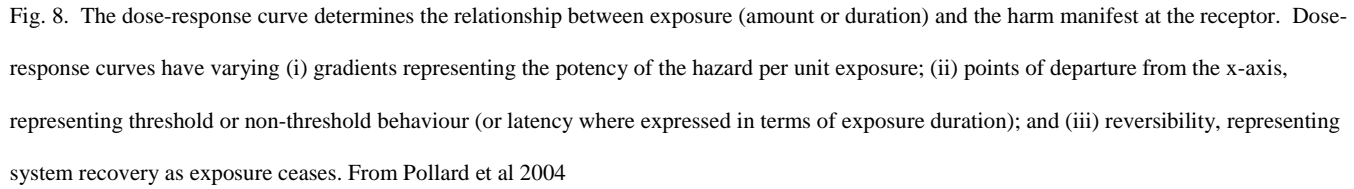

Dose response curves embody both the likelihood and consequences of an effect given that an amount (dose) or duration (time) of exposure occurs. The potency of a hazard on individual receptors is understood by reference to the gradient of dose-response relationship, in that for the same amount of exposure, different sources of a hazard can pose different levels of harm. With respect to sensitivity, some receptors are less resilient to hazards than others. This could be because of their sensitivity to the specific hazard or because they are vulnerable by their very nature. With respect to the magnitude of harm manifest following exposure, we often consider the number of receptors at risk - the population, or 'stock at risk'. Consequences are generally considered to be more significant if a large population of receptors is at risk rather than a small number. This may not be universally applied, however, as we may attach substantial value to even a small number of receptors: single representative habitats, for example.

The requirements of the EC Seveso II (COMAH) Directive to large waste management installations and of the EC Habitats Directive to licensed facilities act as specific drivers for broadening the emphasis of risk management to the off-site receptor (e.g. ecosystem) components of the environment and considering the implications of ecological harm (DETR, 1998, 1999). Furthermore, changes to the human population profile in many countries (increased age, more immunosuppressed people and sensitised sub-populations) have given rise to a greater awareness of sensitive and vulnerable sub-populations. The emphasis for receptor-focused risk studies is on assessing the significance of potential harm at the receptor. This is not trivial and for ecosystems in particular, there is a wide ranging debate over the level at which serious impairment to ecosystem function should be assessed (Smith et al., 2004) and, for human receptors at what level (95\%, 99\% of the populations) protection should and can be afforded.

\section{Integrated risk assessment for multiple receptors}

The future of risk analysis for waste management installations is likely to focus on (i) assessing an expanded set of hazardous circumstances (slope stability, landfill gas, hazardous trace components, issues of odour, risks from unit 
processes, combined events, such as flooding and inventory loss) from individual facilities; (ii) on aggregated risks at integrated, multi-process facilities; and (iii) on the integration of risks that have historically been assessed singularly by reference to individual legislative demands (e.g. Waste Management Licensing (UK), EC Groundwater Directive, EC Habitats Directive). Whilst integration is to be welcomed, its implementation will raise a number of technical and practical challenges for risk analysts, operators and regulators, including:

- $\quad$ a step change in the complexity and likely costs of risk work required of operators;

- the need for commensurate regulatory appraisal of risk assessments submitted in support of environmental permits and, arguably an independent assessment function;

- $\quad$ increased challenges to operators and regulators over the communication of risks to multiple receptors and their relative importance;

- $\quad$ the development and application of new skills in process risk modelling and ecological risk assessment;

- new metrics for the aggregation of risks from multiple technologies and the comparison of risks between distinct endpoints;

- heightened awareness and likely discussion of the potential risks to human health from waste management activities;

- debates about the complex issues involved in comparing risks to different receptors and definitions of risk significance; and

- deciding on appropriate timescales for risk assessments.

Many of these challenges are not new, have been worked through elsewhere internationally and do not require $a$ priori treatment. However, with a more complex picture on the assessment of risk from waste management installations and the increased application of these tools upstream within the decision process during planning, there is a need for a 'route map’ detailing the relative positioning of various tools within the broad context of environmental legislation.

\section{Risk analysis: from strategic to project risk}

Finally, risk analysis is increasingly being used beyond the site-specific project level within (i) the strategic planning of projects; and (ii) for the assessment of risks to and from policies, programmes and plans of work, in a similar way to many environmental appraisal tools (Pollard, 2001). This shift recognizes that decisions made at the site- 
specific level often flounder because of inadequacies in strategic waste planning. Risk assessment becomes fundamental to all phases of the development of waste management facilities. At the strategic 'macro' scale, risk assessments inform strategic decisions about land use planning relying on zoning and vulnerability maps. At an 'intermediate' scale, risk assessments underpin an assessment of the potential impacts associated with a facility’s environmental setting, considered through the development planning process. At the project-specific ('micro' scale) and in the context of environmental permitting, risk assessment is used to enable the operator and regulator to identify the risk management options required to prevent, control, minimise and/or mitigate the risks to the local environment, these becoming stipulated as permit conditions. The increased use of risk assessments at the strategic and development planning stages, usually in support of environmental impact assessments and statements, raises issues about the interface between the assessments submitted at these stages and, where effort is best placed for the benefit of improving overall decisions.

The planning regime generally seeks to avoid commentary on issues that are the preserve of the environmental permitting process although for practitioners, there is merit in developing risk assessments from the strategic to the project level as the site-specificities become clearer. There is a natural progression in the detail and sophistication of assessment as development proceeds. In this context, the spatial dimension of risk is increasingly recognised, and as national, regional and sub-regional waste strategies progress towards implementation and the logistics of waste movements and the siting of new facilities is discussed, the spatial and temporal profile of risks from the new facilities will require analysis.

\section{Conclusions}

Risk-based decision making in waste management is increasingly used outside the established sectors of landfill and hazardous wastes (Milke, 2003). Integrated environmental regulation is leading to risk-based approaches being adopted for site management and the setting of priorities for regulatory inspection (DETR, 1999; Environment Agency, 2004c). However, with increased emphasis on risk-based regulation, a tension exists for practitioners (Tromans, 2004) because concurrent with this expansion is a growing call for simpler, quicker and less costly risk assessments. Balancing the practical value of risk-informed decisions against the resources required to complete complex studies must rank among our future research priorities. Reflecting on current practice, however, we conclude that:

- recent developments in the sector offer a pivotal opportunity to review the application of decision tools for those responsible for managing risk; 
- a more diverse palette of risk tools is required for decision makers wishing to optimise risk management at waste facilities;

- many of these tools can be 'read across' from other disciplines and tailored for the waste sector's needs (Milke, 2003);

- $\quad$ in terms of developing an integrated suite of tools, analogues already exist in the radioactive waste community for the prioritisation of source-pathway-receptor linkages;

- tools for the aggregate and comparative assessment of risks from various waste management options are required by decision-makers optimizing the delivery of a mix of management options co-located at single integrated facilities;

- comparative and integrated options appraisal tools exist for the relative evaluation of environmental, social and financial risk (Pollard et al., 2004) that have direct application within the waste sector.

- $\quad$ integrated risk assessments addressing, and allowing the prioritisation of, the risks to a range of environmental receptors are likely to represent the future;

- $\quad$ benefits to be seized include the reduced costs of gaining environmental permits, improved regulatory and public confidence and the development of a sound and structured approach to managing environmental risk within the sector; and

- sound and well-informed risk management is critical to securing confidence in, and establishing new technologies in a rapidly developing marketplace. 


\section{References}

Attenborough, G.; Hall, DH.; Gregory, RG.; McGoochan, L. GasSim: Landfill gas risk Assessment model. In: Lencioni, E.; Dhamda, R., eds. Waste 2002. Warwick: The Waste Conference Limited; 2002.

BNFL (British Nuclear Fuels Limited). Drigg post-closure safety case: overview report. British Nuclear Fuels Limited: Cumbria; 2002.

BRS (Bureau of Rural Sciences). Risk assessment of abattoir effluent should BSE be found in cattle in Australia (Quinn, DT and Fabiansson, SU). Bureau of Rural Sciences: Kingston; 2001.

CIRIA (Construction Industry Research and Information Association). Design of containment systems for the prevention of water pollution from industrial accidents. Construction Industry Research and Information Association: London; 1997.

Defra (Department of the Environment Food and Rural Affairs) Review of environmental and health effects of waste management: municipal solid waste and similar wastes. Product code PB9052A, Defra: London; 2004. http://www.defra.gov.uk/environment/waste/health-effects/index.htm

DETR (Department of the Environment, Transport and the Regions). Management of harm to the environment: Criteria for the management of unplanned releases. The Stationery Office: London; 1998.

DETR (Department of the Environment, Transport and the Regions). Guidance on the interpretation of major accidents to the environment for the purpose of the COMAH Regulations. The Stationary Office: London; 1999a.

DETR (Department of the Environment, Transport and the Regions). Waste management licensing. Risk assessment inspection frequencies. Operator and pollution risk appraisal for waste “OPRA for waste”. A consultation paper. Her Majesty’s Stationary Office: Norwich; 1999b.

DETR, Environment Agency and Institute for Environment and Health. Guidelines for environmental risk assessment and management - revised departmental guidance. The Stationery Office: London; 2000.

Dolk, H. Methodological issues related to epidemiological assessment of health risks of waste management. In: Hester, R.E.; Harrison, R.M., eds. Environmental and health impact of solid waste management activities. Royal Society of Chemistry: Cambridge; 2002.

Ecke, H.; Lagerkvist, A.; Lundeberg, S.; Assarsson. A. Full-scale anaerobic digestion and composting of source-separated organic municipal solid waste in a novel process. Organic Recovery \& Biological Treatment: Harrogate; 1997.

Eduljee, G. In: Pollard, S.; Guy J., eds. Risk assessment for environmental professionals. Lavenham Press: Suffolk; 2001.

Environment Agency. LandSim: Landfill performance simulation by Monte Carlo method. LandSim Manual, ref CWM 094/96. Environment Agency: Bristol; 1996. www.landsim.com.

Environment Agency. A practical guide to environmental risk assessment for waste management facilities. Environmental Policy Risk and Forecasting Guidance Note 25. Reading: Environment Agency; $2000 . \quad \underline{\text { www.environment- }}$ agency.gov.uk/commondata/105385/gn25_555333.pdf. 
Environment Agency. LandSim Release 2. Landfill performance evaluation. Simulation by Monte Carlo method. R\&D Publication 120. Nottingham: Golder Associates; 2001.

Environment Agency. Guidance on assessment of risks from landfill sites. External consultation. Bristol: Environment Agency; 2004a. http://www.environment-agency.gov.uk/commondata/105385/risk_a_landfills_v1_768278.pdf.

Environment Agency. Improved definition of leachate source term from landfills - Phase 1: review of data from European landfills. Science Report P1-494/SR1. Bristol: Environment Agency; 2004b. http://publications.environmentagency.gov.uk/pdf/SCHO0904BIGD-e-e.pdf.

Environment Agency. Operator pollution risk appraisal (OPRA) waste, and site inspection methodology and report forms. Licensed waste management facility - site inspection methodology and consistent scoring guidelines. Bristol: Environment Agency; 2004c. http://www.environment-agency.gov.uk/business/444217/444661/444671/466170/wasteopra/?lang= e.

European Environment Agency. Environmental risk assessment: approaches, experiences and information sources. Copenhagen: EEA; 1998.

Gale, P. In: Pollard, S.; Guy, J., eds. Risk assessment for environmental professionals. Lavenham Press: Suffolk; 2001.

Garrick, B.J. The use of risk assessment to evaluate waste disposal facilities in the United States of America. Safety Science. 40: 135$151 ; 2002$.

Godfree, A. In: Lowe, P., ed. Pathogens in biosolids and their significance in beneficial use programmes. 6th European biosolids and organic residuals conference, pre-conference workshop proceedings. UKWIR and Aqua Enviro Consultancy Services: Wakefield; 2001.

Hall, D.H.; Drury, D.; Smith, J.; Potter, H.; Gronow, J. Predicting the groundwater impact of modern landfills: Major developments in the approach to landfill risk assessment in the UK (LandSim 2.5). Sardinia: Ninth International Landfill Symposium; 2003.

Hall, D.H.; Gronow, J.; Smith, R.; Blakey, N. Achieving equilibrium status and sustainable landfill - The holy grail? In: Proc. Waste 2004 Conference. Straford-upon-Avon, Warwickshire: The Waste Conference Limited; 2004.

Harrop, D.O.; Pollard, S.J.T. Risk assessment and waste-to-energy plants (incineration). Quantitative risk assessment for Incineration: is it Appropriate for the UK? J CIWEM 12(1): 48-53; 1998.

HSE (Health and Safety Executive). Good practice and pitfalls in risk assessment. Health and Safety Laboratory Research Report 151. Sudbury, Suffolk: HSE Books; 2003.

Hester, R.E.; Harrison, R.M. eds. Environmental and health impact of solid waste management activities. Cambridge: Royal Society of Chemistry; 2002.

Hirschhorn, J.S. Mad cow and related diseases: challenges for waste management. Remediation, Autumn: 87-107; 1999.

Hobbs, S.E., Longhurst, P.; Sarkar, U. Dispersion of odour: a case study with a municipal solid waste (MSW) landfill site in North London, United Kingdom. J. Environ. Manage. 68(2): 153-160; 2003. 
Mills, W.J.; Bennett, E.R.; Schmidt, C.E.; Thibodeaux, L.J. Obtaining quantitative vapor emissions estimates of polychlorinated biphenyls and other semivolatile organic compounds from contaminated sites. Environ. Tox. Chem. 23(10): 2457-2464; 2004. Milke, M.W. Improving our ability to manage risks. Waste Management 23: iii-iv; 2003.

National Research Council. Waste incineration and public health. Washington DC: National Academy Press; 2000.

NEA (Nuclear Energy Authority). Confidence in the long-term safety of deep geological repositories. Paris: OECD; 1999.

Pollard, S.J.T.; Harrop, D.O.; Crowcroft, P.; Mallett, S.H.; Jefferies, S.R.; Young, P.J. Risk assessment for environmental management: approaches and applications. J. CIWEM. 9(6): 621-628; 1995.

Pollard, S.J.T.; Timmis, R.; Robertson, S. In: Exposure assessment in the evaluation of risk to human health. RATSC Workshop Report (cr5). University of Leicester: Institute for Environment and Health; 1999.

Pollard, S.; Guy, J. eds. Risk assessment for environmental professionals, Suffolk: Lavenham Press; 2001.

Pollard, S.J.T.; Yearsley, R.; Reynard, N.; Meadowcroft, I.C.; Duarte-Davidson, R.; Duerden, S. Current directions in the practice of environmental risk assessment in the United Kingdom. Environ. Sci. Technol. 36(4): 530-538; 2002.

Pollard, S.J.T; Kemp, R.V.; Crawford, M.; Duarte-Davidson, R.; Irwin, J.G.; Yearsley, R. Characterising environmental harm: Developments in an approach to strategic risk assessment and risk management, Risk Anal. 24(6): 1551-1560; 2004.

Rabl, A.; Spadaro, J.J. In: Hester, R.E.; Harrison, R.M. eds. Environmental and health impact of solid waste management activities. Cambridge: Royal Society of Chemistry; 2002.

Senante, E. Odour management at municipal wastewater and waste treatment units operated by SUEZ ENVIRONMENT. In: Environmental odour management, International conference VDI und DIN: Cologne; 2004.

Schnoor, J. Environmental modelling: fate and transport of pollutants in water, air and soil. Chichester: John Wiley \& Sons; 1996.

Shanks Waste Services. In: Environmental impact assessment for Calvert landfill site. Bedfordshire County Council. Cranfield: Cranfield University; 2003.

Shaw, R.; Lucas, J.; Naisbitt, N. Planning and permit applications for a proposed hazardous waste disposal facility - a case study. In: Lencioni E.; Dhamda, R.. eds. Waste 2002. Warwick: The Waste Conference Limited; 2002.

Smith, R.; Pollard, S.J.T.; Weeks, J.M.; Nathanial, C.P. Assessing significant harm to ecosystems from contaminated land. J. Soil Use Manage. in press; 2004.

South West Public Health Observatory. Waste management and public health: the state of the evidence. South West Public Health Observatory; 2002. http://www.swpho.org.uk/waste/.

Steinheider, B.; Both, R.; Winneke, G. Field studies on environmental odours including annoyance as well as gastric and general health-related symptoms. J. Psychophysiology. 12: 64-79; 1998.

Taha, M.P.M.; Pollard, S.J.T. Emission and dispersal of bioaerosols during the agitation of green waste compost piles. In: Waste 2004. Warwick: The Waste Conference Limited; 2004.

Tromans, S. Risk-based regulation: A new Jerusalem? Environmentalist. 25: 42; 2004. 

International conference VDI und DIN: Cologne; 2004.

Vose, D. Quantitative risk analysis: a guide to Monte Carlo simulation modelling. $2^{\text {nd }}$ Edition. Chichester: John Wiley and Sons; 2000.

Watts, L. Development of the post-closure safety case for the low level waste disposal site, UK. In: McGrail, B.P.; Cragnolino, G.A. eds. Scientific basis for nuclear waste management XXV. MRS Proceedings; 2001.

WHO (World Health Organisation). Methods of assessing risk to health from exposure to hazards released from waste landfills.

Report of a WHO meeting, Lodz, Poland. Copenhagen: World Health Organisation Regional Office for Europe; 2000.

9 Water Research Centre (WRc). Quantitative risk assessment for BSE infectivity in discharge consent. Medmenham: WRc; 1998.

10 Yearsley, R.; Summerling, T.J. Some questions on the use of long time scales for radioactive waste disposal safety assessments. In:

NEA workshop on the handling of time scales assessing post-closure safety. Paris: Nuclear Energy Agency; 2002. 
Figures for Inclusion in Article

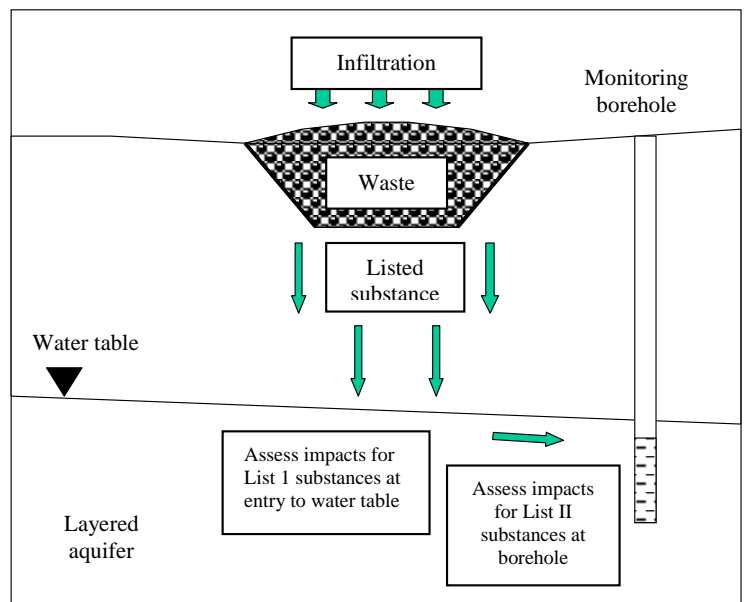

Fig. 1. Basis for the combined performance and risk assessment of landfills and their potential impact on downgradient abstraction points, here by reference to listed substances in the EC Groundwater Directive (Environment Agency, 2000).

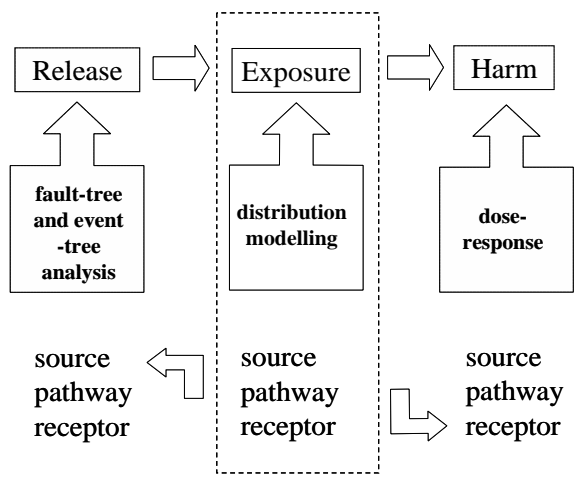

Key

ind

Conventional domain of

environmental risk

assessment for waste

management facilities

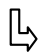

Direction of change showing

increased emphasis on

'upstream' process risk issues

and 'downstream' receptor

issues

Fig.2. Basic typology of risk assessment tools and emphasis. 


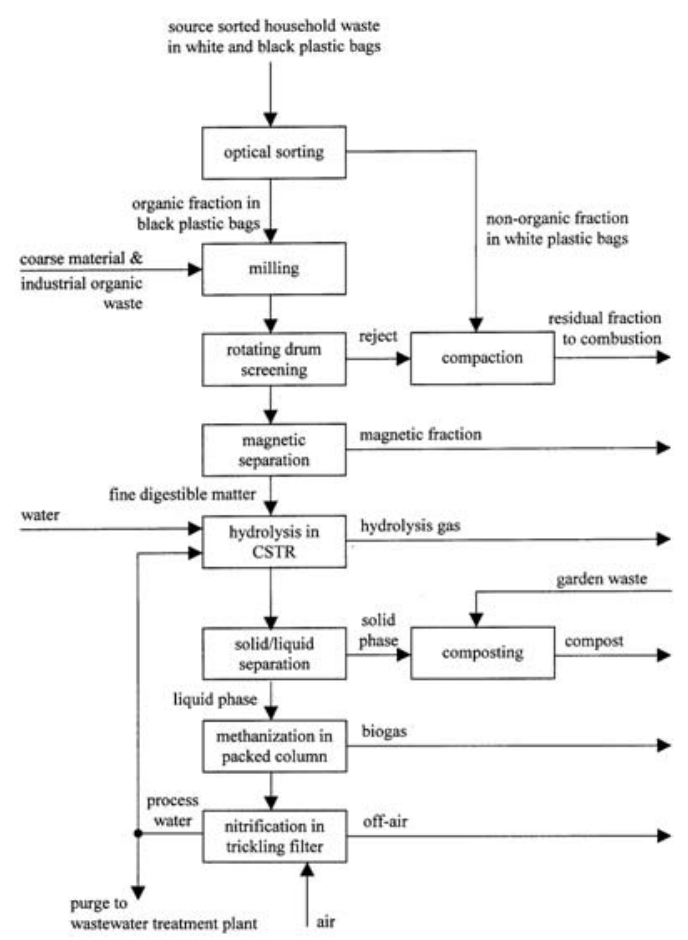

2 Fig. 3. Simplified process flowsheet for the two-step anaerobic degradation plant, Sobacken, Borås, Sweden for wet organic household waste (after

3 Ecke et al., 1997). The unit process sequence includes a mixing tank, a hydrolysis reactor, dewatering, a methanogenic filter and a nitrification tower.

4 The plant started operation in 1995 with an annual capacity of $c a$. $9000 \mathrm{t}$ of organic waste fraction. The digestate is post-treated by composting. 


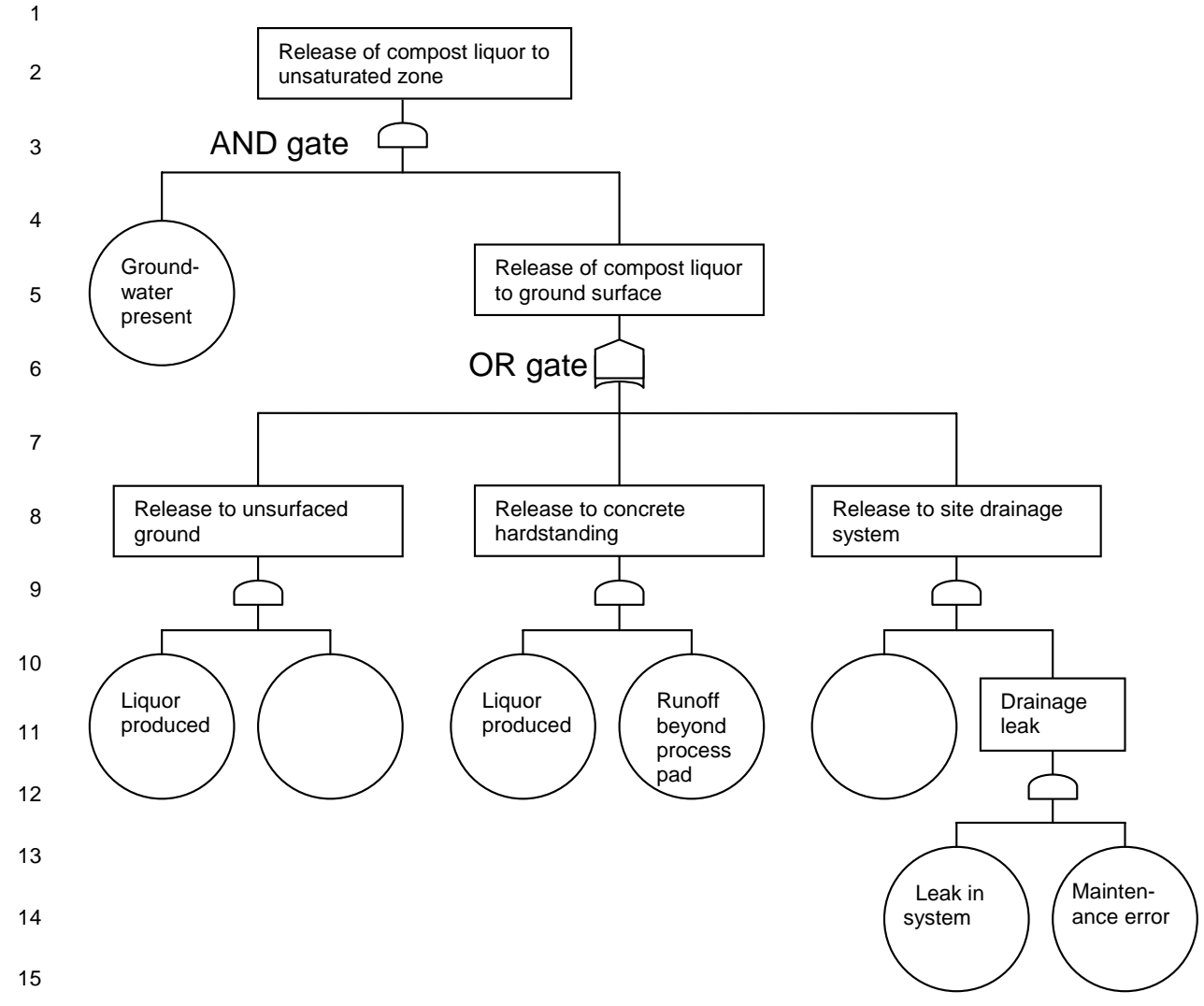

16 Fig. 4 Illustrative and qualitative fault-tree for release of compost liquor to groundwater at a composting plant showing AND and OR gates. 
1

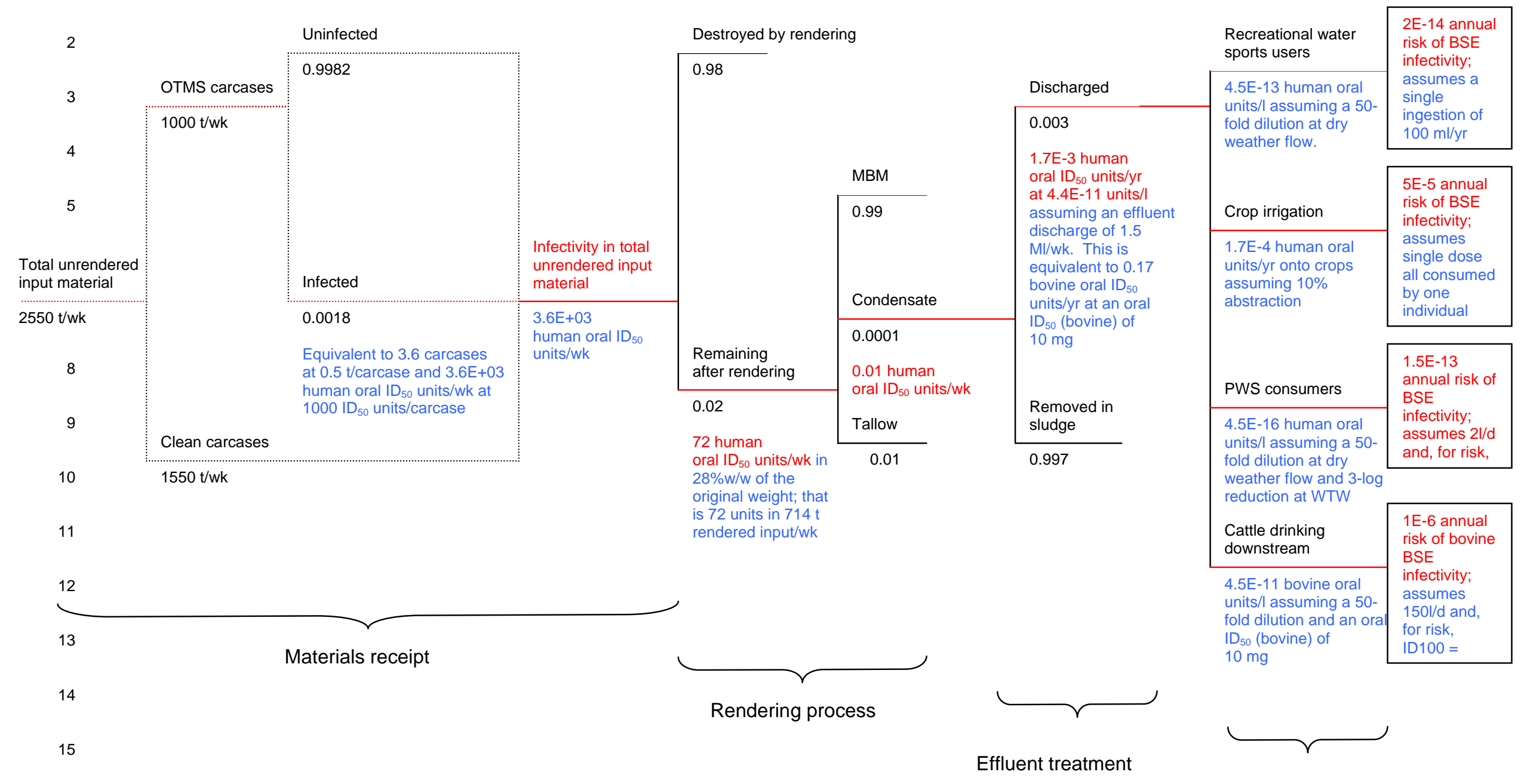

16

Exposure assessment

17 Fig. 5 Illustrative event tree for of the fate of infective doses (ID) of pathogenic agents during the proposed rendering of over thirty month scheme (OTMS) material in a fictitious rendering plant (adapted

18 from WRc, 1998, used with permission) Need to state what PWS and MBM stand for, or spell in full in figure or in text 


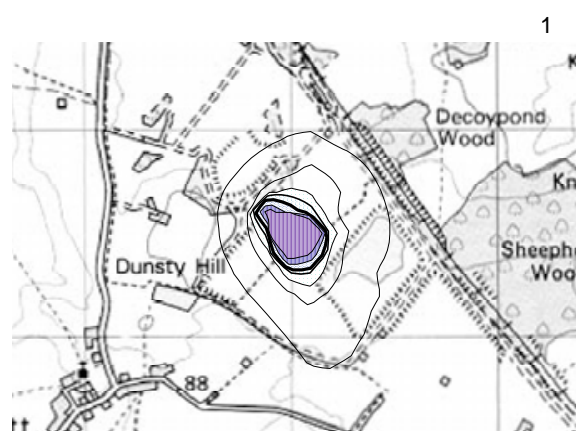

7 Fig. 6. The application of distribution models in exposure assessment for amenity risk assessment. Map shows contours of increasing odour units (ou; (Shanks Waste Services, 2003; location plan reproduced from the revised 1998 Ordnance Survey 1:50 000 Landranger map No. 153 with the permission of the Controller of Her Majesty’s Stationery Office, (c) Crown copyright.)

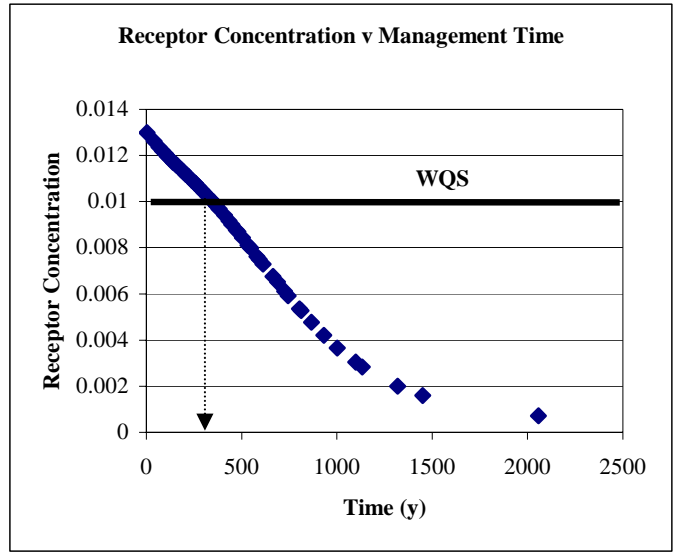

Fig.7. Estimated management period of $340 \mathrm{y}$ for a non-flushing landfill accepting raw municipal solid wastes (MSW)

and meeting the water quality standard (WQS) for lead at a groundwater receptor (after Hall et al., 2004) 


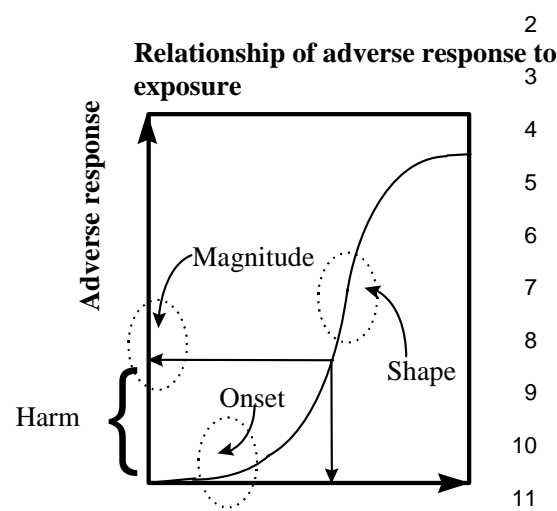

Amount / duration of exposure

4

8 e

Fig. 8. The dose-response curve determines the relationship between exposure (amount or duration) and the harm manifest at the receptor. Doseresponse curves have varying (i) gradients representing the potency of the hazard per unit exposure; (ii) points of departure from the x-axis,

representing threshold or non-threshold behaviour (or latency where expressed in terms of exposure duration); and (iii) reversibility, representing system recovery as exposure ceases. From Pollard et al 2004 